\title{
Why Do Saudi EFL Readers Exhibit Poor Reading Abilities?
}

\author{
Abdulaziz Ali Al-Qahtani ${ }^{1}$ \\ ${ }^{1}$ School of Education, Communication and Language Sciences, Newcastle University, Newcastle upon Tyne, UK \\ Correspondence: Abdulaziz Ali Al-Qahtani, School of Education, Communication and Language Sciences, \\ Newcastle University, Newcastle upon Tyne, NE1 7RU, United Kingdom. E-mail: a.al-qahtani@newcastle.ac.uk
}

\author{
Received: January 4, 2016 Accepted: January 19, 2016 Online Published: February 26, 2016 \\ doi:10.5539/ells.v6n1p1 URL: http://dx.doi.org/10.5539/ells.v6n1p1
}

\begin{abstract}
The aim of the current study was to investigate the reasons behind Saudi learners' poor reading skills. To this end, the objectives were to identify the reading habits of Saudi English as a Foreign Language (EFL) middle school learners, to understand the extent to which Saudi EFL middle school learners use reading comprehension skills and to explore the perceptions of learners, teachers and supervisors regarding Saudi EFL learners' reading abilities. The study sample consisted of 90 Saudi EFL middle school students, eight EFL teachers and six supervisors. The students were surveyed and interviewed about their reading habits and use of reading skills, while the teachers and supervisors were interviewed to explore their perceptions about reading instruction in the Saudi context. The results revealed that most Saudi EFL students lack the necessary reading habits in L1 and L2. In addition, they rarely make use of important reading skills when they read English texts. This study identified "lack of exposure to target language", "poor teaching skills and teacher training programs", "little attention to comprehension and more attention to reading aloud", "students' lack of motivation", "little emphasis on reading skills in textbooks", "unfamiliar and unsuitable reading topics", "lack of reading skills training for students", "students" limited vocabulary" and "lack of parental involvement" as the most important factors behind Saudi students' poor reading abilities. The study concluded with important recommendations and suggestions for future research.
\end{abstract}

Keywords: EFL, Saudi readers, reading habits, reading skills

\section{Introduction}

The public educational system in Saudi Arabia adopts a gender separation policy and consists of three levels: elementary (from the age of 6), intermediate (grades 7 to 9) and secondary (grades 10 to 12). Generally, students are assessed through examinations and need to score at least $50 \%$ in each taught subject to move on to the next level (Al-Roomy, 2013).

English was first taught at the intermediate and secondary levels in Saudi Arabia in 1927 and was begun to be taught at the elementary level in 2005 (Alamri, 2008; Al-Qahtani, 2010). Students learn English at the elementary stage from the fourth grade onwards (two classes per week). At the intermediate level, students have four 45-mintue English periods a week, while at the secondary stage students have four or five English lessons per week, depending on the type of school system (the Saudi Ministry of Education is piloting a number of new school systems, especially for the secondary stage). Despite the fact that the Saudi educational system has included the teaching of English for a very long time, students' proficiency in English in general and in reading in particular is far from satisfactory (Al-Karroud, 2005; Al-Qahtani, 2010; Al-Roomy, 2013).

In reviewing recent, although limited, studies on Saudi EFL learners' English proficiency, Saudi students appear to have very limited vocabulary ( 890 of the 5,000 most common English words). They also seem to be unmotivated and lack basic communicative abilities (Nezami, 2012). These issues can be attributed to a number of factors, such as inefficient teaching instruction, inappropriate teaching materials, lack of practice in class, insufficient teacher training, the backwash effect of testing on learning and teaching, lack of exposure to the target language and the limited time allocated to learning English at school (Al-Sadan, 2000; Alzahrani, 2009; Al-Mansour, 2009; Gawi, 2012). In addition to the above, there is noticeable inconsistency between textbooks used at the three levels of education because the Ministry of Education has assigned different textbooks designed by different publishers to different school levels. This problematic situation of textbook selection might create long-term problems for EFL teachers and learners. 
With regard to reading skill, Saudi learners obviously share the same difficulties other Arab EFL learners have when reading English texts. In fact, according to TOEFL and IELTS data summary reports, Saudi test takers' level of reading proficiency is the lowest worldwide (IELTS, 2012; Educational Testing Services, 2009, 2010, 2011, 2012, 2013). Nezami (2012) conducted a study to investigate university level EFL Saudi learners' comprehension strategies and reading skills and identified the following as major problems for Saudi EFL readers:

- Limited vocabulary

- Difficulty in understanding the meaning of text

- Lack of self-study activities

- Spelling and pronunciation problems

- Disinterest in collaborative work and group discussions

- Lack of extensive reading

- Difficulties in scanning and skimming

- Lack of motivation

- Syntactic parsing difficulties

- Difficulties in prediction and in using prior knowledge

- Inability to summarize a text

Al Nooh \& Mosson-McPherson (2013) surveyed a group of Saudi secondary stage EFL learners and EFL teachers to identify learners' reading problems. They concluded that concentration, overall comprehension, reading fluency, motivation and retention were among the problematic variables that influence their reading achievement. Learners stated that decoding sounds and words, reading books of their own choosing, listening to the teacher read aloud to the class, scaffolding, systematic vocabulary instruction and reading aloud are among the most effective techniques they need to understand English texts reasonably well.

Some of the most cited factors that influence the current EFL reading situation in Saudi Arabia and other Gulf countries include the reading culture in the L1 community; L1 reading standards; background knowledge; methods of reading instruction; backwash from testing and learners' motivation (O'Sullivan, 2004). First, reading in the Saudi community is not popular. In fact, Saudi students are poor readers in their mother tongue as they rarely read for pleasure (NEXT PAGE, 2007). The situation is the same as regards reading English texts (Al-Nujaidi, 2003). Second, standardized Arabic is not common in the Saudi community, as local dialects are more prevalent. This has created a unique situation in which reading skills in standardized Arabic are at the second language level, whereas English reading skills are at the third language level (O'Sullivan, 2004). Third, background knowledge is a factor that can hinder or facilitate reading. Saudi students appear to lack certain general background knowledge and global awareness. This can be attributed to learners' reading habits in both L1 and L2 (Alsamadani, 2009). Fourth, reading instruction in Saudi Arabia is problematic. A number of studies maintain that Saudi EFL teachers are not highly qualified and lack proper training to implement effective teaching methods (Al-Hazmi, 2003; Bersamina, 2009). In fact, much of the teaching inside the classroom is test-driven instruction that is generally geared towards passing the final exams (Mustafa, 2002). Fifth, using standardized tests at schools has led learners to believe that reading in English is just part of school work and nothing more, which prevents transferring successful L1 strategies to L2 (Wurr, 2003). Sixth, viewing English as only a school subject might have negatively influenced Saudi EFL readers' attitudes and motivation as they would only pursue reading in English for academic purposes (O'Sullivan, 2004).

The interest in conducting this study stems from the unsatisfactory reading abilities of Saudi EFL learners and the gap in the literature on Saudi EFL readers' low proficiency in terms of reading skills. Exploring intermediate stage EFL learners' reading comprehension has been largely ignored in previous studies compared to studies of tertiary level EFL learners. The current study attempted to investigate the reasons behind Saudi learners' poor reading skills. To this end, the following research questions were developed:

1) What are the reading habits of Saudi EFL middle school learners?

2) To what extent do Saudi EFL middle school learners use reading comprehension skills?

3) What are the perceptions of learners, teachers and supervisors regarding Saudi EFL learners' reading abilities? 
This study facilitates understanding of the issue of poor reading abilities among Saudi students, which can be approached from different perspectives based on the views of learners, teachers and supervisors. It also attempts to provide important suggestions to Saudi educational policymakers, course designers, educators and parents to improve Saudi EFL learners' reading abilities. Therefore, the results of this study may be of benefit in second-language reading instruction in general.

Following this introduction, the methodological approach adopted in this study will be presented. The major research instruments (reading habits questionnaire and reading skills questionnaire) are identified and the procedures followed in collecting and analysing the data are described. Key results from an analysis of the research data are presented and discussed, along with implications and recommendations for future research

\section{Methods}

\subsection{Participants}

Three third-grade classes comprising 90 EFL learners were chosen from a public school in Jeddah city. Students were all male Saudis whose first language is Arabic and were between the ages of 15 and 16. They had been learning English for four years before they progressed to the third-grade level, and their exposure to the target language outside the classroom was very limited except for television programmes or social media networks, which do not replace real face-to-face interaction or help maintain a considerable progress in language proficiency. Thirteen of these students were interviewed to explore their perceptions and feelings about their reading skills and the reasons for having those views. Eight Saudi EFL middle school teachers and six EFL supervisors also took part in the study. They were chosen based on the level they teach, their experience and their willingness to participate. They were interviewed to find out their thoughts and perceptions on students' reading comprehension in Saudi public schools.

\subsection{Instruments}

\subsubsection{Students' Reading Questionnaire}

The second questionnaire that was designed for students is the reading questionnaire. Its purpose was to explore students' reading habits and to find out the extent to which they are exposed to reading in their native language and in English. The questionnaire also aimed at identifying the extent to which students practice English language reading skills.

The first part concerned identifying students' reading habits in Arabic and in English. It consisted of 10 questions that enquired about how often they read outside school, whether they read enough, the number of books they have at home, the type of reading materials they prefer to read and the people who inspire them to read. These questions were developed based on reading questionnaires that were used in a number of other studies (e.g., Iftanti, 2012; Tamrackitkun, 2010; West, 2010; Clark \& Foster, 2005; Hull \& Schultz, 2001).

The objective of the second part of the reading questionnaire was to identify how frequently EFL learners use reading comprehension skills. Although the possibility of identifying independent reading skills and sub-skills is a very controversial issue, the fact that reading skills taxonomy is available is "enormously pervasive and influential" (Alderson, 2000, p. 10). In fact, it is quite difficult to investigate reading as a process or as a product or even to construct a reading comprehension test without some kind of identified reading comprehension skills to guide this effort.

In order to construct the questionnaire, a number of reading skills taxonomies from a wide range of studies and language proficiency tests were reviewed (e.g., Al-Roomy, 2013; Hessamy, 2013; Pan \& Wu, 2013; El-Safory, 2011; Shang, 2011; Kaya, 2010; Liu, 2010; Cheng, 2009; Davis, 1968; Munby, 1978; Grabe, 1991; Weir, 1997; Barati, 2005; IELTS, 2012, 2014; TOEFL, 2012). After examining these studies and tests, the questionnaire in this study was developed to include four types of reading: careful local reading, careful global reading, expeditious local reading and expeditious global reading (Hessamy, 2013; Barati, 2005; Urquhart \& Weir, 1998; Weir, 1997). For each type of reading, a number of sub-skills were identified as the basis of the developed 28 -item questionnaire. Thus, the questionnaire could be considered comprehensive and thorough enough to cover most, if not all, the identified reading comprehension skills and sub-skills found in the reviewed works.

The questionnaire used a six-point Likert scale. Participants indicated their opinions of the 28 statements by marking "always", "most of the time", "sometimes", "rarely", "never" or "I do not know". The items were translated from English into Arabic, and the translation was reviewed by two native speakers of Arabic who are also English instructors. The necessary corrections were made based on their comments.

The questionnaire was piloted online at the same middle school in which the attitude questionnaire was piloted. 
A Cronbach's alpha test was run to establish the reliability of the questionnaire. The reliability of the piloted questionnaire was 0.96 , which is considered an excellent reliability coefficient (George \& Mallery, 2003).

After the piloting, necessary adjustments and corrections were made. For instance, the translations of items (6), (11) and (27) were modified to clear up any ambiguities. Moreover, the last column in the scale, "I do not know", was deleted because students found it confusing and difficult to differentiate from the column "rarely".

\subsubsection{Semi-structured Interviews}

After administering the questionnaire, 13 third grade middle school EFL learners, eight EFL middle school teachers and six EFL supervisors were interviewed. Students were interviewed at the school's English Language Centre (which was quiet, well facilitated and relaxing), while the interviews with teachers and supervisors were held at The Southern Office of Educational Supervision in Jeddah. The duration of each interview session ranged approximately between 30 and 45 minutes, and they were conducted in the participants' first language to overcome concerns about foreign language proficiency or miscommunication. The questions considered general and easy to answer were asked at the beginning of the interview in order to engage respondents and put them at ease. Each interview was digitally audio-recorded to help gather as much relevant data as possible and so the interviewer could remain attentive to the interviewees during the sessions. There was a concern regarding the age difference between the researcher and the student interviewees, but the significant experience of the researcher as a school teacher and a supervisor helped substantially in conducting the interviews successfully.

The students' interview schedule consisted of a series of questions that explored their reading habits in Arabic and in English. Students were also asked about their personal stories of learning English and their experience in learning to read in English in classroom contexts. For example, students were asked about the importance of English, how reading is taught in Saudi classrooms, how they actually read a textbook passage for comprehension, what problems they encounter while reading and how they overcome them and what type of reading texts they prefer.

The teachers' interview schedule explored Saudi EFL teachers' views on students' level of proficiency in English in general and in reading English texts in particular. The EFL supervisors' interview was similar to the teachers' interview. It looked at supervisors' takes on teaching/learning reading. It was important to include the thoughts and views of those who work closely with EFL teachers and learners as they are responsible for visiting and evaluating teachers and checking students' progress in learning English. The information they offered provided valuable insights on issues related to the current study.

\subsection{Procedures}

Initially, the three third grade intermediate classes from the school that facilitated the experiment responded to the questionnaire about their reading habits and skills. After answering the questionnaires, 13 student volunteers, and supervisors and eight EFL teachers who teach the same grade level were interviewed. The participating students were chosen based on their English language proficiency (five high, four medium and four low), whereas the teachers were chosen based on their teaching experience (from novice to experienced). The aim of these interviews was to allow the participants to express their views on reading instruction in the Saudi EFL context.

\section{Results}

As this study is interested in reading skill, it was thought a good idea to explore learners' reading habits first as they might contribute to the understanding of learners' current reading proficiency level.

\subsection{Students' Reading Habits}

In this part of questionnaire, students were asked 10 questions to explore their reading habits in Arabic (the native language) and in English (the target language). Obviously, the first question to ask was whether students read at home. The results show that two fifths of the students (40\%) reported that they never read in Arabic at home, and the majority of them (63\%) do not read in English (see Figure 1). 
Do you read at home?

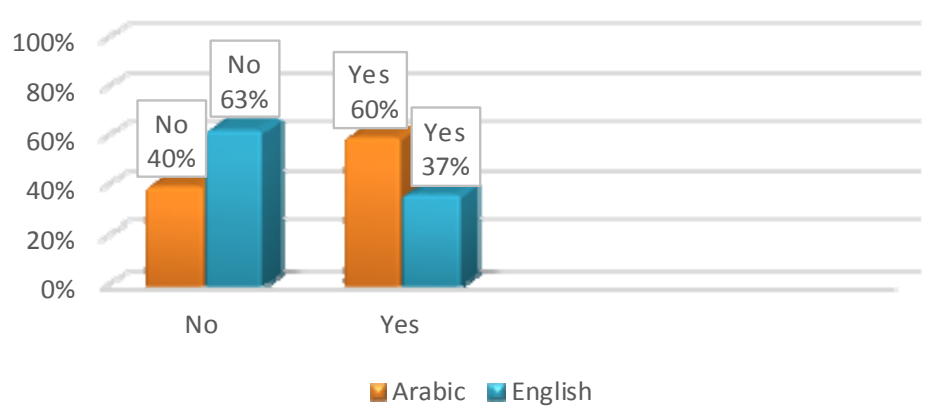

Figure 1. Do you read at home?

Of those who read on a daily basis, only $11 \%$ read in Arabic and none read in English. The majority of students read in Arabic once or twice a week (63\%), and nearly two thirds of them read once or twice a month. Regarding reading in English, almost half of the students read once or twice a week, whereas the other half read once or twice a month (see Figure 2).

\section{How often do you read at home?}

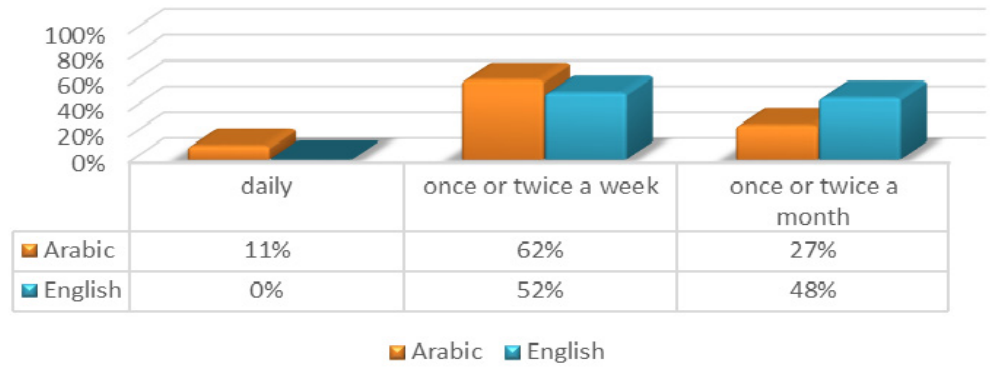

Figure 2. How often do you read at home?

When students were asked whether they "read enough", the majority reported they do not read enough, even though they want to read in both languages (90\% in Arabic and 86\% in English). Only 4\% of the students believe they read enough English, and $9 \%$ of them just do not wish to read in the target language. Similar results were found regarding reading in Arabic (see Figure 3).

\section{Do you think you read enough?}

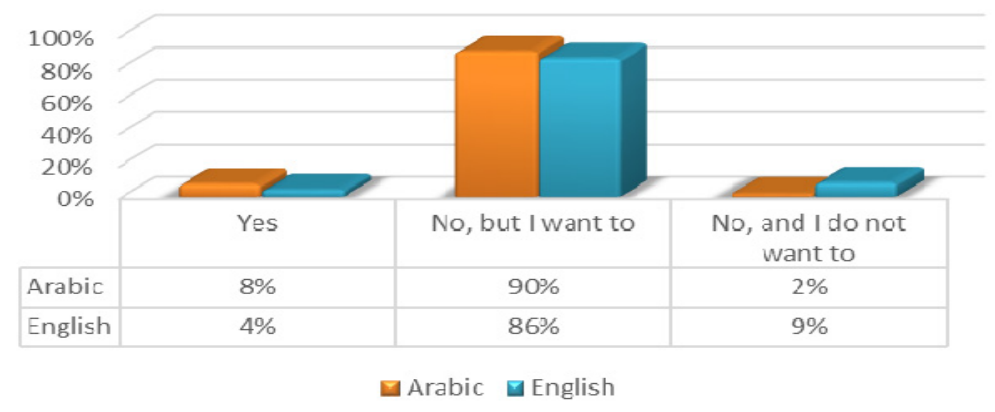

Figure 3. Do you think you read enough?

With regard to students' preference to read, similar results were found between Arabic and English. Almost one third of the students like to read in both languages from electronic sources with limited word counts, such as 
communication networks, e-mails and text messages, and approximately one quarter of the students prefer to read short stories. The students were least interested in reading poetry and novels (see Figure 4).

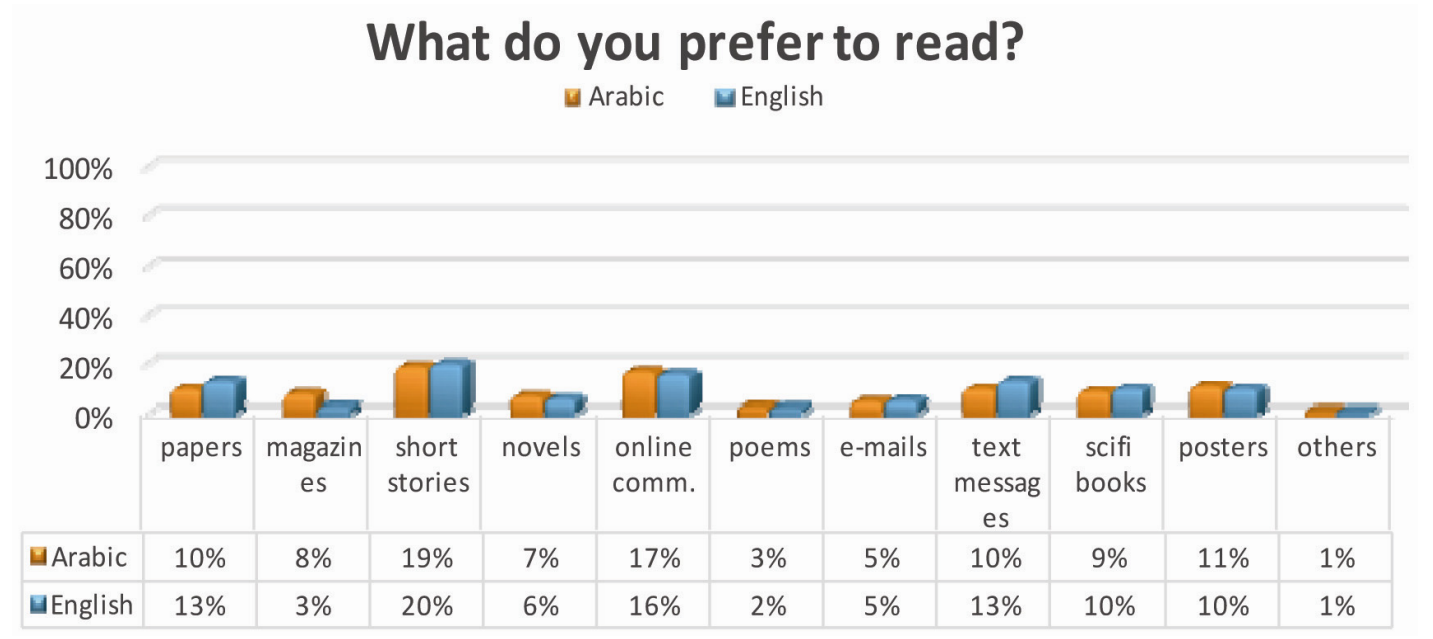

Figure 4. What do you prefer to read?

The results were similar in both languages when students were asked about the people who have the most influence on them regarding reading (Figure 5). More than one third of the students reported that teachers are their first source of motivation to read. After teachers, family members were considered the next most influential in increasing students' interest in reading in Arabic (28\%) and in English (30\%). According to students' responses, self-motivation was ranked third in terms of motivating them to read (27\% in Arabic and $23 \%$ in English). Friends seemed to be the least influential in motivating students to read. It is worth mentioning that there were no significant differences between teachers, family and self-motivation, indicating they have similar influence in the drive to read. However, the results indicate that the students are highly extrinsically motivated, as more than $77 \%$ believe that the sources of inspiration for them to read are their teachers, family members and peers.

\section{Who motivates you to read?}

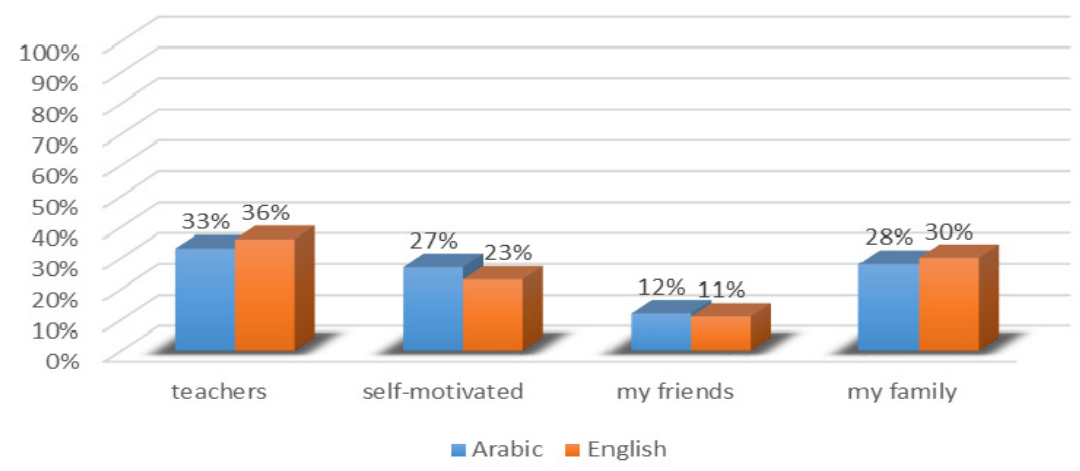

Figure 5. Who motivates you to read?

The questionnaire findings seem to be corroborated by the data gathered from the students' interviews. Many of the 14 students interviewed indicated that they rarely read in Arabic, especially those with low and intermediate levels of reading proficiency in English. For example, Ali said: "I do not read much. If I read, I would read for about 10 minutes". Omar commented that: "I read in Arabic every other week for a short time, and it is not a lot." Students at these levels tend to read very short texts, such as text messages, newspaper headlines and social media postings, such as those on Facebook, Instagram and WhatsApp. With regard to reading in English, these students hardly read anything. Omar, for example, acknowledged that: "I do not read outside the class. I do need to read more English to improve my language skills". When asked about why they do not read enough English, if 
any, Saif, Hani, Sultan and Omar indicated that "lack of interest", "poor reading skills", "socio-economic status" and "ineffective teaching practice" were the main reasons for their inability to read well in English.

Students with a higher level of reading proficiency in English seem to read more in their first language. For instance, Naser stated that: "In my free time, I read my favourite novel. I also read short stories and magazines". Some students, like Samir, have their own personal library. These students liked to read extended texts, such as novels, stories and newspaper articles in addition to information on available social media networks. Students at this level indicated that family members and teachers were the main sources of motivation for them to read. For instance, Ahmad said: "I am really enthusiastic about reading in English. It is all because of my family. My brother used to read to me his English textbooks when I was young. My father, too, helped me learn to read". Samir stated that: "My teacher encourages me to read. He praises me when I make the effort to read in English. I really like English because of him". Self-motivation was also evident in their responses, as they understood the importance of being able to read in English and the positive influence it might have on their future education and careers.

\subsection{Students' Use of Reading Skills}

In this part of questionnaire, students were surveyed to explore the extent to which they use reading skills in reading lessons. The questionnaire comprised 28 items and was developed to include the two types of reading, "careful reading" and "expeditious reading". These two types of reading were based on the works of Hessamy (2013), Barati (2005), Weir (2004), Urquhart \& Weir (1998) and Weir (1997). Thus, the questionnaire was comprehensive enough to embody the identified reading comprehension skills and sub-skills in major studies.

The questionnaire was administered to the three participating classes. Table 1 shows some revealing results about the extent to which participants from the three classes believe they use careful reading skills.

Table 1. Students' use of careful reading skills

\begin{tabular}{|c|c|c|c|c|c|c|c|c|c|c|c|}
\hline & \multirow[t]{2}{*}{ Item } & \multicolumn{2}{|c|}{ always } & \multicolumn{2}{|c|}{ mostly } & \multicolumn{2}{|c|}{ sometimes } & \multicolumn{2}{|c|}{ rarely } & \multicolumn{2}{|c|}{ never } \\
\hline & & $\mathrm{N}$ & $\%$ & $\mathrm{~N}$ & $\%$ & $\mathrm{~N}$ & $\%$ & $\mathrm{~N}$ & $\%$ & $\mathrm{~N}$ & $\%$ \\
\hline 1 & $\begin{array}{l}\text { I can guess the meaning of an unfamiliar word by its } \\
\text { position in a sentence. (e.g., nouns, verbs, adjectives) }\end{array}$ & 0 & $0 \%$ & 3 & $3 \%$ & 28 & $31 \%$ & 55 & $61 \%$ & 4 & $4 \%$ \\
\hline 2 & $\begin{array}{l}\text { I can answer questions about the information or facts } \\
\text { that are clearly stated in the text. }\end{array}$ & 0 & $0 \%$ & 1 & $1 \%$ & 18 & $20 \%$ & 36 & $40 \%$ & 35 & $39 \%$ \\
\hline 3 & $\begin{array}{l}\text { I can make use of prefixes, suffixes and word roots to } \\
\text { guess the meaning of unfamiliar words (e.g., unhappy = } \\
\text { un (not) }+ \text { happy; teacher = teach }+ \text { er; - -logy = science). }\end{array}$ & 0 & $0 \%$ & 3 & $3 \%$ & 21 & $23 \%$ & 48 & $53 \%$ & 18 & $20 \%$ \\
\hline 4 & $\begin{array}{l}\text { I can draw conclusions from information that is not } \\
\text { explicitly stated. }\end{array}$ & 0 & $0 \%$ & 6 & $7 \%$ & 21 & $23 \%$ & 32 & $36 \%$ & 31 & $34 \%$ \\
\hline 5 & $\begin{array}{l}\text { I can guess the meaning of unfamiliar words by } \\
\text { examining contextual clues, such as synonyms, } \\
\text { antonyms and examples. }\end{array}$ & 0 & $0 \%$ & 2 & $2 \%$ & 22 & $24 \%$ & 44 & $49 \%$ & 22 & $24 \%$ \\
\hline 6 & I can understand the implications of the passage. & 0 & $0 \%$ & 3 & $3 \%$ & 16 & $18 \%$ & 46 & $51 \%$ & 25 & $28 \%$ \\
\hline 7 & I can interpret pronouns when I read a given text. & 0 & $0 \%$ & 3 & $3 \%$ & 23 & $26 \%$ & 47 & $52 \%$ & 17 & $19 \%$ \\
\hline 8 & $\begin{array}{l}\text { I can make use of discourse markers in the text (e.g., } \\
\text { however/for example/ In addition) to aid my } \\
\text { understanding. }\end{array}$ & 0 & $0 \%$ & 3 & $3 \%$ & 16 & $18 \%$ & 47 & $52 \%$ & 24 & $27 \%$ \\
\hline 9 & I can distinguish between facts and opinions in the text. & 0 & $0 \%$ & 0 & $0 \%$ & 22 & $24 \%$ & 51 & $57 \%$ & 17 & $19 \%$ \\
\hline 10 & $\begin{array}{l}\text { I can recognize the purpose of sentences in the text (e.g., } \\
\text { providing a definition, a description, an apology or } \\
\text { instructions). }\end{array}$ & 0 & $0 \%$ & 1 & $1 \%$ & 24 & $27 \%$ & 45 & $50 \%$ & 20 & $22 \%$ \\
\hline 11 & I can recognize the author's attitude and bias. & 0 & $0 \%$ & 4 & $4 \%$ & 20 & $22 \%$ & 49 & $54 \%$ & 17 & $19 \%$ \\
\hline 12 & I can rearrange scrambled sentences or paragraphs. & 0 & $0 \%$ & 0 & $0 \%$ & 27 & $30 \%$ & 43 & $48 \%$ & 20 & $22 \%$ \\
\hline 13 & $\begin{array}{l}\text { I can recognize the type of text I am reading (e.g., } \\
\text { instructive/descriptive/informative). }\end{array}$ & 0 & $0 \%$ & 2 & $2 \%$ & 15 & $17 \%$ & 51 & $57 \%$ & 22 & $24 \%$ \\
\hline \multicolumn{2}{|c|}{ TOTAL } & 0 & $0 \%$ & 30 & $2 \%$ & 273 & $23 \%$ & 594 & $50 \%$ & 301 & $26 \%$ \\
\hline
\end{tabular}

Based on Table 1, almost $75 \%$ of the participants "rarely" or "never" use careful reading skills. Also, one quarter of the respondents reported that they "sometimes" apply these skills, and only $2 \%$ believed they "mostly" use careful skills. However, none of the students indicated that they "always" employ these skills when reading texts. Almost identical results were obtained regarding “expeditious reading” skills (see Table 2 below). 
Table 2. Students' use of expeditious reading skills

\begin{tabular}{|c|c|c|c|c|c|c|c|c|c|c|c|}
\hline & \multirow[t]{2}{*}{ Item } & \multicolumn{2}{|c|}{ always } & \multicolumn{2}{|c|}{ mostly } & \multicolumn{2}{|c|}{ sometimes } & \multicolumn{2}{|c|}{ rarely } & \multicolumn{2}{|c|}{ never } \\
\hline & & $\mathrm{N}$ & $\%$ & $\mathrm{~N}$ & $\%$ & $\mathrm{~N}$ & $\%$ & $\mathrm{~N}$ & $\%$ & $\mathrm{~N}$ & $\%$ \\
\hline 1 & $\begin{array}{l}\text { I can guess the meaning of an unfamiliar word by its } \\
\text { position in a sentence. (e.g., nouns, verbs, adjectives). }\end{array}$ & 0 & $0 \%$ & 1 & $1 \%$ & 9 & $10 \%$ & 51 & $57 \%$ & 29 & $32 \%$ \\
\hline 2 & $\begin{array}{l}\text { I can answer questions about the information or facts } \\
\text { that are clearly stated in the text. }\end{array}$ & 0 & $0 \%$ & 2 & $2 \%$ & 19 & $21 \%$ & 33 & $37 \%$ & 36 & $40 \%$ \\
\hline 3 & $\begin{array}{l}\text { I can make use of prefixes, suffixes and word roots to } \\
\text { guess the meaning of unfamiliar words (e.g., unhappy = } \\
\text { un (not) }+ \text { happy; teacher }=\text { teach }+ \text { er; }-\operatorname{logy}=\text { science). }\end{array}$ & 0 & $0 \%$ & 6 & $7 \%$ & 26 & $29 \%$ & 36 & $40 \%$ & 22 & $24 \%$ \\
\hline 4 & $\begin{array}{l}\text { I can draw conclusions from information that is not } \\
\text { explicitly stated. }\end{array}$ & 0 & $0 \%$ & 4 & $4 \%$ & 26 & $29 \%$ & 39 & $43 \%$ & 21 & $23 \%$ \\
\hline 5 & $\begin{array}{l}\text { I can guess the meaning of unfamiliar words by } \\
\text { examining contextual clues, such as synonyms, } \\
\text { antonyms and examples. }\end{array}$ & 0 & $0 \%$ & 3 & $3 \%$ & 21 & $23 \%$ & 49 & $54 \%$ & 17 & $19 \%$ \\
\hline 6 & I can understand the implications of the passage. & 0 & $0 \%$ & 2 & $2 \%$ & 23 & $26 \%$ & 47 & $52 \%$ & 18 & $20 \%$ \\
\hline 7 & I can interpret pronouns when I read a given text. & 0 & $0 \%$ & 3 & $3 \%$ & 30 & $33 \%$ & 38 & $42 \%$ & 19 & $21 \%$ \\
\hline 8 & $\begin{array}{l}\text { I can make use of discourse markers in the text (e.g., } \\
\text { however/for example/ In addition) to aid my } \\
\text { understanding. }\end{array}$ & 0 & $0 \%$ & 1 & $1 \%$ & 26 & $29 \%$ & 46 & $51 \%$ & 17 & $19 \%$ \\
\hline 9 & $\begin{array}{l}\text { I can make use of the words that are bold faced, in italics } \\
\text { or in a different font size, style or colour to help me find } \\
\text { what I am looking for. }\end{array}$ & 0 & $0 \%$ & 1 & $1 \%$ & 24 & $27 \%$ & 42 & $47 \%$ & 23 & $26 \%$ \\
\hline 10 & $\begin{array}{l}\text { I can read a text quickly and get the most important } \\
\text { information from it. }\end{array}$ & 0 & $0 \%$ & 2 & $2 \%$ & 21 & $23 \%$ & 52 & $58 \%$ & 15 & $17 \%$ \\
\hline 11 & $\begin{array}{l}\text { I can make use of transitional phrases (e.g., first, second, } \\
\text { then, however, moreover) when I try to find specific } \\
\text { information. }\end{array}$ & 0 & $0 \%$ & 1 & $1 \%$ & 22 & $24 \%$ & 45 & $50 \%$ & 22 & $24 \%$ \\
\hline 12 & $\begin{array}{l}\text { Before I read, I run my eyes over the text and notice } \\
\text { names, numbers and italicized words so that I can get a } \\
\text { general understanding of the text. }\end{array}$ & 0 & $0 \%$ & 2 & $2 \%$ & 17 & $19 \%$ & 50 & $56 \%$ & 21 & $23 \%$ \\
\hline 13 & $\begin{array}{l}\text { I can make use of key words or phrases in the text to } \\
\text { help me answer a specific question. }\end{array}$ & 0 & $0 \%$ & 1 & $1 \%$ & 17 & $19 \%$ & 52 & $58 \%$ & 20 & $22 \%$ \\
\hline 14 & $\begin{array}{l}\text { Before I read a passage, I look at the first few sentences } \\
\text { of each paragraph so that I can understand the central } \\
\text { idea of the text. }\end{array}$ & 0 & $0 \%$ & 0 & $0 \%$ & 15 & $17 \%$ & 58 & $64 \%$ & 17 & $19 \%$ \\
\hline $\mathbf{T O}^{\prime}$ & $\mathbf{A L}$ & 0 & $0 \%$ & 29 & $2 \%$ & 296 & $23 \%$ & 638 & $51 \%$ & 297 & $24 \%$ \\
\hline
\end{tabular}

In addition to the quantitative data generated by the questionnaire, Saudi EFL learners, teachers and supervisors were interviewed to explore how students read English passages, the reading difficulties they face when they read and how students are usually taught in Saudi EFL reading classes.

\subsubsection{EFL Learners' Perceptions}

When students were presented with some reading text samples extracted from the textbook they were going to study during the semester and asked about how they approach reading them, they responded as follows:

- Jalal: "I read the title. Then, I just start reading the rest. I take it in small portions. When I start answering comprehension questions, I just look for words in the passage that are similar to those in the questions and copy and paste the whole thing."

- Omar: "I start by looking at the pictures to understand the general idea. I read the title and then I read the passage right from the start. I mostly read word by word and underline key words, which I ask the teacher about their meaning. But I am still unsuccessful at understanding."

- Saif: "I look at the title. Then, I read on. However, I frequently stop because of unknown words."

- Saud: "First, I look at the title and then I read silently. I keep on reading even if I come across new vocabulary. I try to guess its meaning from the context, but understanding the passage is still a major problem for me because of it."

- Ali: "I just cannot read. I understand $0 \%$ of what I read."

An examination of these accounts, among others, reveals that very few students demonstrated good knowledge 
of expeditious reading skills, such as previewing and skimming, or of careful reading skills, such as guessing the meaning of unfamiliar words using contextual clues. The majority of students were unfamiliar with reading skills in general and how to read passages appropriately. The accounts also highlight the importance and the integrative nature of careful reading and expeditious reading skills in the process of comprehension. For instance, Saud mentions the use of expeditious reading skills but also expressed the frustration he feels because inefficient careful reading skills hinder his comprehension of the passage. Furthermore, data from the interviews highlight the issue of mixed-ability classes and having students with a wide range of reading abilities in the same reading class.

When students were asked about the difficulties they encounter while they read, almost all mentioned "meaning and pronunciation of new vocabulary" as the main concern. Some students, such as Omar, Majed and Hani, indicated that "badly structured texts", "lack of pictures and illustrations" and "complex sentence structure and grammar" were major problems for them when they read. Others, such as Saif and Ahmad, blamed themselves for their "unwillingness to make a real effort" to read and learn how to read and their teachers because of their ineffective "teaching methods and styles".

With regard to teaching methods, students were asked to comment on how they are taught during reading lessons and whether they had received any previous training on reading skills. Following are a few of their responses.

- Ahmad: "The teacher starts by asking: who wants to read loudly? If no one volunteers, he randomly chooses. This takes half of the class time. He then asks us to read silently and asks us about our understanding of the passage in Arabic. After that, he tells us to answer the questions individually. Sometimes he answers the first question for us and leaves the rest for us to answer on our own. The lesson ends with a review of our answers. Teachers in general do not tolerate miscomprehension or mistakes."

- Nasser: "I remember three types of teachers. The first type would start by reading the whole passage aloud. He then translates it into Arabic. Finally, we are asked to answer the questions after he translates them for us. The second type of teachers would ask us to read silently and then they select some students to read aloud. After that, they ask students to translate as much as they can before we answer the comprehension questions. The third type of teacher randomly selects some students to read aloud. Then, they choose some key words and ask about their meaning. If no one knows, teachers would translate. Finally, we answer the questions and review the answers with teachers to make the necessary corrections."

- Hani: "The teacher starts the reading lesson by first playing a recording of the passage twice while we follow. Then, he explains the meaning of the passage as well as the comprehension questions in Arabic. The teacher plays the recording a second time and picks only those who want to participate and lets them answer the questions."

By examining these responses, as well as other students' comments, reading lessons appeared to be mainly teacher-centred, poorly structured and L1-oriented. The teaching practice seemed to lack appropriate reading stages (pre, while and post) activities and little attention was paid to drilling crucial reading skills in both careful and expeditious types of reading. In fact, all participants (after explaining key reading skills) indicated that they had never been involved in any kind of reading skills training organized by their teachers at any point in their school life. In addition, there seemed to be a general emphasis by teachers on reading aloud and checking students' pronunciation, as Jalal, Ali and Nasser pointed out in the interviews.

In some cases, students were left to read silently and then answer the comprehension questions on their own. In other cases, teachers wrote the answers to comprehension questions on the board and asked students to copy them in their notebooks, as indicated by Omar and Ahmad. These teaching practices are not conducive to improving students' thinking skills, as they provide little room for successful communication, discussions or the sharing of ideas and thoughts between learners and teachers and among learners themselves.

\subsubsection{EFL Teachers' Perceptions}

In an attempt to understand the full picture of Saudi EFL learners' reading comprehension skills, eight teachers were interviewed. They were asked for their opinions of their students' reading skills and the reasons for having those views. All the interviewed teachers indicated that Saudi EFL learners' reading abilities are generally poor. For example, Hameed (20 years of experience) described students as "unmotivated", "struggling" and "in constant need of help" during reading lessons. Mohammad (12 years of experience) stated that "Students are superficial, they read lines but they cannot read between the lines. A considerable number of them cannot even read letters correctly." Mansouri (10 years of experience) believed that the level of Saudi students' reading skills is "far below the average" and that they "cannot even understand the main idea of what they read". Ahmad (7 
years of experience) further claimed that almost " $80 \%$ of students do not understand English texts".

In the interviews, teachers attributed this bleak picture of Saudi students' reading skills to a variety of internal and external factors. As for the internal factors, most teachers believed students' "overall low level of language proficiency" and "limited vocabulary" are at the heart of the problem. For example, Hisham (25 years of experience) said: "For 25 years, I had to devote the first two to three weeks to teaching students the English alphabets. Students are not proficient enough". Mohammad agreed, commenting that: "We teachers emphasize grammar and vocabulary instead of focusing on developing students' reading skills because of their low proficiency level". Ahmad stated that students "know very few English words that they are unable to understand reading passages".

Poor reading skills in students' native language were reported by some teachers as having a major effect on students' reading skills in the target language. Hameed stated that "We are a nation that does not read. How do you expect students who cannot read well in their own mother tongue to read properly in another language?" This point was reiterated by Abdulla (14 years of experience), who commented that "We do not read enough in Arabic and in English".

Many teachers reported students' lack of interest in reading as a major problem that ultimately leads to poor reading comprehension skills. When teachers were asked to trace back the roots of students' disinterest, some of them, such as Hameed, mentioned that students became "too much involved with modern technology, especially smart phone applications and text messaging". Because of this, students do not spend enough time on reading academic texts or longer texts of different genres. However, Noor claimed that there is a "negative social attitude towards learning English" that affects students' interest in reading English texts. He maintains that "learning English is an unreligious thing to do. Instead, students should learn Arabic, the language of the Holy Qur'an". However, this view was not shared by the majority of the interviewees (students, teachers and supervisors), who stressed the importance of learning English for various reasons.

With regard to external reasons, many teachers considered the "prescribed English textbooks" responsible for Saudi students' poor reading skills. For instance, Noor (5 years of experience) stated that "The current textbooks contain insufficient reading activities and they do not emphasize reading skill". Hameed spoke of the problem of textbooks' contents and continuous replacements. He stated that

The frequent changing of textbooks is very disturbing for teacher and students as well. Whenever we familiarize ourselves with one textbook, we are asked to teach a new one. Also, the textbooks we are teaching now have too many lessons, unfamiliar topics and long lists of vocabulary items; things we cannot go through within the class time-limit. And I believe that these textbooks do not pay the proper attention to developing students' reading skills.

Related to the problems with EFL textbooks is the gap between teachers and policymakers in the Ministry of Education. Hameed complained that "There is poor communication between us and local and central educational authorities". In his opinion, many complaints, suggestions and ideas are not "taken seriously" and cannot be communicated and shared with officials at higher levels in the Saudi educational system because of its highly centralized and hierarchical structure. Teachers feel they are not involved in making important decisions about the design and selection of appropriate textbooks. Moreover, teachers, such as Mansouri, complained that "in-service teacher-training programs are insufficient". These programs are, according to him "a key issue in updating and developing teaching English language skills including reading". Noor indicated that there is a need to add more English classes to the school timetables, as he believes that "four periods a week are not good enough". These observations, and many more, can only be addressed by the central authority in the Ministry of Education, which does not seem to have strong cooperative ties with fieldwork practitioners, such as supervisors and teachers.

Some of the interviewed teachers blamed their fellow teachers for students' poor reading skills. For example, Hisham pointed out that there are: "many incompetent teachers" and that they simply "ignore students learning needs". Abdullah described them as being "passive and unmotivated to work on improving their students' reading skills". Mansouri added that "Teachers themselves are not proficient in English language" and that "they are unfamiliar with recent developments in language teaching". In fact, teaching grammar and translation seemed to be common in reading classes, as stated by many teachers. This issue takes us back to what was discussed previously about insufficient and ineffective in-service teaching programs.

Some teachers held parents responsible for their children's poor reading comprehension skills. Hameed stated that "Some parents are not supportive. They do not encourage their children to read in their own native language, let alone in English." He stated that children need a "role model" at home that inspires and motivates them to 
develop a positive attitude towards reading. He went on to say "I am a teacher and a parent. I do not read a lot and I truly feel responsible for my son's insufficient reading practice". Ahmad and Abdullah maintained that some parents show little interest in cooperating with teachers to encourage their children to read and improve their reading habits. Hisham feared that we are increasingly moving towards being a "non-reader culture" because of parents' disregard of the importance of reading when in fact family could play a key role in fostering and developing reading skills in children, particularly from an early age.

A group of teachers identified "lack of exposure to English" as a general problem that negatively affects students' language abilities. Abdullah explained that

English in Saudi Arabia is a foreign language. Our students do not practice English outside schools. In fact, they have got less than 45 minutes to do so. It is even much less than 45 minutes as teachers spend quite a lot of time on classroom discipline, checking homework and attendance, organizing materials and explaining questions and concepts. Students do not really spend enough time practicing reading and other language skills. I believe they need more time.

It is quite difficult to imagine how students can improve their reading skills when they do not have enough opportunities to practice these skills, at least inside language classrooms. Hisham commented on this by criticizing how EFL teachers in Saudi schools teach English. He said that

After 25 years of teaching and observing other teachers, I can say that English is taught as a subject, not as a language. Teachers take over most of the class time while students sit passively. And to make things even worse, Arabic is the dominant language in class!

This comment, coming from a very experienced teacher, demonstrates how lack of exposure can be a huge problem inside language classrooms as much as it is a problem outside schools. It sheds light on issues like teacher-centred classrooms and excessive use of first language. In addition, it points to the fact that treating English as only an exam-oriented school subject and not as a medium of communication can have negative consequences in terms of students' language abilities. In Hisham's own words, the outcome of such an approach is "almost zero".

\subsubsection{EFL Supervisors' Perceptions}

The perceptions of EFL supervisors regarding students' reading skills were quite similar to those of teachers. All six supervisors interviewed reported that Saudi students' reading comprehension skills are "extremely poor", "way below the expected level" and "really disappointing". In fact, Osama went on to say that: "Almost $70 \%$ of them [students] are not proficient enough to comprehend a text, even those who are beyond secondary stage".

There seems to be strong agreement between supervisors and teachers when supervisors were asked about the factors that contributed to students' poor reading abilities. The responses they provided almost mirrored the reasons identified by teachers. However, most of them placed more emphasis on issues like "lack of exposure to target language", "poor teaching skills and teacher training programmes", "little attention to comprehension and more attention to reading aloud", "students" lack of motivation", "little emphasis on reading skills in textbooks", "unfamiliar and unsuitable reading topics", "lack of reading skills training for students" and "students' limited vocabulary".

\section{Discussion}

This study investigated students' habits and their use of reading skills in order to understand Saudi learners' current reading proficiency levels. To achieve this, the participants were surveyed and interviewed about their reading habits in Arabic and in English. They were also asked about their use of reading skills. The results obtained from an analysis of the questionnaires and interview data were presented in the previous section. An overview of the key findings with respect to this research question will be provided next, and a more detailed discussion and recommendations will follow.

With regard to Saudi EFL students' reading habits in both Arabic and English, the findings of this study agrees with many Arab world studies (e.g., Jraissati, 2010; Bendriss \& Golkowska, 2011; Hanna, 2011; Al-Yacoub, 2012; Kechichian, 2012) that concluded that Arab students of all levels, including Saudis, do not read enough, if at all. The findings of this study are also in agreement with Saudi studies (e.g., Rajab \& Al-Sadi, 2015; Al-Mansour \& Al-Shorman, 2011; Al-Musallam, 2009) that show that Saudi students have a low tendency to read in Arabic and in English. In fact, Al-Nujaidi (2003) found that the majority of Saudi students do not read outside school. Moreover, the study confirms the findings of Rajab \& Al-Sadi (2015), which indicated that Saudi students spend a considerable amount of time using social media and reading social media posts. Therefore, as Rajab and Al-Sadi point out, it is more appropriate to label Saudi students "unmotivated readers" rather than 
"non-readers". In this respect, the current study reveals that teachers, family members and self-motivation are all crucial in motivating students to read in both target and native languages. Yet, as the findings of this study suggest, the motivation factor can interact with other internal and external factors that were mentioned in the previous section.

Those factors may also explain the findings of this study regarding students' poor use of careful and expeditious reading skills. In fact, this study confirms the findings of Alsamadani (2011) by indicating that there is a huge gap between Saudi students' actual reading proficiency level and their expected reading proficiency, even at the university level. However, the literature on reading suggests other factors that might have contributed to students' poor reading comprehension. Among the most cited factors affecting the Saudi Arabian reading context include the reading culture in the L1 community, L1 reading standards, background knowledge and backwash from testing (O'Sullivan, 2004). Standardized Arabic is not common in the Saudi community as local dialects are more prevalent. This results in a unique situation in which reading skills in standardized Arabic are at the second language level, whereas English reading skills are at the third language level. In addition, other reader and text variables are significant in explaining the problems Saudi EFL readers face. On one hand, reader variables include readers' linguistic knowledge (L2 culture, phonology, syntax, morphology, orthography and semantics), metalinguistic knowledge and discourse knowledge. On the other hand, text variables involve text topic, genre, organization, linguistic features and readability. In fact, this discussion demonstrates the complexity of reading skill, as there are many interconnected variables involved. To address each of them would be a huge undertaking.

Based on the findings of this study, a number of recommendations can be made. First, there is a need to promote reading in students' first language and in target languages and to make students want to read. This can be accomplished by supporting the use of school/class libraries and encouraging teachers to make reading more attractive to students. Providing students with a reading-friendly environment with plenty of suitable and interesting reading material might prompt students to establish and maintain good reading habits, which could lead them to become effective readers. Second, it is crucial to have intensive reading program that explicitly teach students important reading skills in both the native and target languages. This lends support to the developmental interdependence theory, which hypothesizes that reading across all languages is associated with common abilities that can be transferred from the native language to the target language when an L1 reader's reading abilities reach a certain level (Genesee, Lindholm-Leary, Saunders, \& Christian, 2006). This also supports the language threshold theory, which holds that a certain level (threshold) of linguistic proficiency in L2 needs to be attained before L1 linguistic skills can be transferred to facilitate L2 reading (Lems, Miller, \& Soro, 2010). Third, it is necessary to stress the importance of pre-service and in-service teacher training on reading skills instruction, as the findings of previous studies and of the present study show that teachers lack the necessary knowledge about reading skills and ways in which they can be promoted. Fourth, great care should be given to students' intrinsic and extrinsic motivation if any success is to be achieved in developing students' reading comprehension. Fifth, this study highlights the need for effective parental involvement in students' education. It provides a range of benefits for parents and children, including improvements in reading abilities (Frank \& Rosén, 2008; Sylva, Melhuish, Sammons, Siraj-Blatchford, \& Taggart, 2004).

Suggestions for further research include extending this study to other EFL contexts (within the same region or beyond) in order to compare and contrast findings and to develop a framework for improving reading comprehension skills that is generalizable and flexible. Another suggestion is to examine the effect of programs to develop reading habits in first and target languages on students' reading skills and attitudes. A further suggestion is to investigate the effect of explicit teaching of reading skills in both native and target languages on young learners and to identify the effect of this on students' acquisition of reading skills and attitudes.

\section{References}

Al Nooh, A. M.-M., M. (2013). The effectiveness of reading techniques used in a Saudi Arabian secondary school classroom as perceived by students and teachers: A study of methods used in teaching English and their effectiveness. Arab World English Journal, 4(3), 331-345.

Alamri, A. M. (2008). An evaluation of the sixth grade English language (MA thesis). Retrieved from http://faculty.ksu.edu.sa/amri/Documents/MA\%20thesis.pdf

Alderson, J. C. (2000). Assessing reading. Cambridge: Cambridge University Press. http://dx.doi.org/10.1017/CBO9780511732935

Al-Hazmi, S. H. (2003). EFL teacher preparation programs in Saudi Arabia: Trends and challenges. TESOL Quarterly, 37(2), 341-344. http://dx.doi.org/10.2307/3588509 
Al-Karroud, I. (2005). New, interesting methods and techniques: English as it should be taught. Al-Ma'rifah Journal, 1, 120.

Al-Mansour, N. (2009). Bilingualism and the need for early EFL education in the Kingdom of Saudi Arabia. King Saud University Languages \& Translation Journal, 21, 1-12.

Al-Mansour, N. S., \& Al-Shorman, R. E. A. (2011). The effect of teacher's storytelling aloud on the reading comprehension of Saudi elementary stage students. Journal of King Saud University, Languages and Translation, 23(2), 69-76. http://dx.doi.org/10.1016/j.jksult.2011.04.001

Al-Musallam, E. I. (2009). College instructors' and learners' attitudes to authentic EFL reading materials in Saudi Arabia (Unpublished doctoral dissertation). King Saud University, Saudi Arabia.

Al-Nujaidi, A. (2003). The relationship between vocabulary size, reading strategies, and reading comprehension of EFL learners in Saudi Arabia (Unpublished doctoral dissertation). Oklahoma State University, USA.

Al-Qahtani, A. (2010). The effectiveness of metacognitive strategies on secondary stage students' achievement and attitudes towards English language (MA thesis). Taif University, Saudi Arabia.

Al-Roomy, M. (2013). An action research study of collaborative strategic reading in English with Saudi medical students (PhD thesis). University of Sussex, UK.

Al-Sadan, A. (2000). Educational assessment in Saudi Arabian schools. Assessment in Education: Principles, Policy \& Practice, 7(1), 143-155. http://dx.doi.org/10.1080/713613320

Alsamadani, H. (2009). The relationship between Saudi EFL college-level students' use of reading strategies and their EFL reading comprehension (Unpublished doctoral dissertation). Ohio University, USA.

Alsamadani, H. (2011). Saudi students' awareness of reading strategies and factors affecting their EFL reading comprehension. British Journal of Arts and Social Sciences, 2(2), 75-87.

Al-Yacoub, I. (2012). Sum of all fears: Arabs read an average of 6 pages a year, study reveals. From Al Arabiya News Online. Retrieved from http://www.alarabiya.net/articles/2012/07/14/226290.html

Alzahrani, J. (2009). Saudi secondary school male students' attitudes towards English: An exploratory study. King Saud University Languages \& Translation Journal, 20, 25-36.

Barati, H. (2005). Test taking strategies and the assessment of reading skills: An approach to construct validation (Unpublished doctoral dissertation). University of Bristol, UK.

Bendriss, R., \& Golkowska, K. (2011). Early reading habits and their impact on the reading literacy of Qatari undergraduate students. Arab World English Journal, 2(4), 37-57.

Bersamina, F. V. (2009). English as second language (ESL) learners in Saudi Arabia. Associated Content Society. Retrieved from www.associatedcontent.com

Cheng, M. (2009). Effects of English proficiency and gender on reading strategy use. Taiwan: National Pingtung Institute of Commerce.

Clark, C. F. A. (2005). Children's and young peoples'reading habits and preferences: The who, what, why, where and when. London: National Literacy Trust.

Davis, F. B. (1968). Research in comprehension in reading. Reading Research Quarterly, 3, 499-545. http://dx.doi.org/10.2307/747153

Educational Testing Services. (2009, 2010, 2011, 2012, 2013). Test and score data summary for TOEFL Internet-based and paper-based tests. Retrieved from: http://www.ets.org

El-Safory, K. (2011). The effectiveness of some metacognitive strategies in developing reading comprehension among the second grade preparatory students (MA thesis). Ain Shams University, Egypt.

Frank, E. (2008). On the importance of parental participation for student achievement in reading literacy. Paper presented at The 3rd IEA International Research Conference, Chinese Taipei, Taiwan.

Gawi, A. (2012). The effects of age factor on learning English: A case study of learning English in Saudi schools, Saudi Arabia. English Language Teaching, 5(1), 127-139.

Genesee, F., Lindholm-Leary, K., Saunders, W. M., \& Christian, D. (2006). Educating English language learners: A synthesis of research evidence. New York: Cambridge University Press. http://dx.doi.org/10.1017/CBO9780511499913

George, D., \& Mallery, P. (2003). SPSS for Windows step by step: A simple guide and reference (4th ed.). Boston: 
Allyn \& Bacon.

Grabe, W. (1991). Current developments in second language reading research. TESOL Quarterly, 25, 375-406. http://dx.doi.org/10.2307/3586977

Hanna, J. (2011). I read, therefore, I am. Highlights -University of Balamand Student Newspaper, 11. Retrieved from

http://www.balamand.edu.lb/Offices/AdministrativeOffices/StudentAffairs/CampusLife/Documents/Hi ghlights/Highlights-Issue11.pdf

Hessamy, G. (2013). Construct validity of careful vs. expeditious reading skills. International Journal of English Language Education, 1(3), 223-243. http://dx.doi.org/10.5296/ijele.v1i3.4018

Hull, G., \& Schultz, K. (2001). Literacy and learning out of school: A review of theory and research. Review of Educational Research, 71(4), 575-612. http://dx.doi.org/10.3102/00346543071004575

IELTS. (2012). Test taker performance 2012. Retrieved from http://www.ielts.org/researchers/analysis-of-test-data/test-taker-performance-2012.aspx

IELTS. (2014). IELTS: Analysis of test data: Percentile ranks 2012. Retrieved from http://www.ielts.org/researchers/analysis_of_test_data/percentile_ranks_2012.aspx

Iftanti, E. (2012). A survey of the English reading habits of EFL students in Indonesia. TEFLIN Journal, 23(2), $149-164$.

Jraissati, Y. (2010). Who said Arabs don't read? Retrieved from http://jraissati.com/2010/10/who-said-arabs-dont-read/

Kaya, E. (2010). The role of reading skills on reading comprehension ability of Turkish EFL students (Unpublished Master's thesis). Çukurova University, Turkey.

Kechichian, J. A. (2012). Arab populations don't read enough. Gulf News Newspaper. Retrieved from http://gulfnews.com/opinions/columnists/arab-populations-don-t-read-enough-1.1023935

Lems, K., Miller, L. D., \& Soro, T. M. (2010). Teaching reading to English language learners: Insights from linguistics. New York: The Guilford Press.

Liu, F. (2010). Reading abilities and strategies: A short introduction. International Education Studies, 3(3), 153-157. http://dx.doi.org/10.5539/ies.v3n3p153

Munby, J. (1978). Communicative syllabus design. Cambridge: Cambridge University Press.

Mustafa, G. (2002). English Language teaching and learning at government schools in the United Arab Emirates (Unpublished doctoral dissertation). University of Exeter, UK.

Nezami, S. (2012). A critical study of comprehension strategies and general problems in reading skill faced by Arab EFL learners with special reference to Najran University in Saudi Arabia. International Journal of Social Sciences and Education, 2(3), 306-316.

O'Sullivan, A. (2004). Reading and Arab college students-Issues in the United Arab Emirates higher colleges of technology. Retrieved from: https://www.academia.edu/1012284/Reading_and_Arab_college_students_Issues_in_the_United_Arab _Emirates_Higher_Colleges_of_Technology

Pan, C. Y., \& Wu, H. Y. (2013). The cooperative learning effects on English reading comprehension and learning motivation of EFL freshmen. English Language Teaching, 6(5), 13-27. http://dx.doi.org/10.5539/elt.v6n5p13

Rajab, H., \& Al-Sadi, A. (2015). An empirical study of reading habits and interests of Saudi university EFL learners. International Journal of Linguistics, 7(2), 1-17.

Shahini, G., \& Riazi, A. M. (2010). A PBLT approach to teaching ESL speaking, writing, and thinking skills. ELT Journal.

Shang, H. (2011). Exploring the relationship between EFL proficiency level and reading strategy use. International Journal of Humanities and Social Science, 1(3), 18-27.

Sylva, K., Melhuish, E., Sammons, P., Siraj-Blatchford, I., \& Taggart, B. (2004). Effective pre-school education. Final report. DFES. London: Institute of Education.

Tamrackitkun, K. (2010). Extensive reading: An empirical study of its effects on EFL Thai students' reading 
comprehension, reading fluency and attitudes (Unpublished $\mathrm{PhD}$ thesis). University of Salford, UK.

Urquhart, A. H., \& Weir, C. J. (1998). Reading in a second language: Process, product and practice. London and New York: Longman.

Weir, C. (1997). The testing of reading in a second language. In C. Clapham \& D. Corson (Eds.), Encyclopedia of langue and education, Language testing and assessment (Vol. 7, pp. 11-49). Netherlands: Kluwer Academic Publishers. http://dx.doi.org/10.1007/978-1-4020-4489-2_5

West, C. (2010). Secondary students' reading attitudes and achievement in a scaffolded silent reading program versus traditional sustained silent reading ( $\mathrm{PhD}$ thesis). Auburn University, USA, Retrieved from http://etd.auburn.edu/etd/bitstream/handle/10415/2279/Chandra\%20West\%20Dissertation\%207-23-10. pdf

\section{Copyrights}

Copyright for this article is retained by the author(s), with first publication rights granted to the journal.

This is an open-access article distributed under the terms and conditions of the Creative Commons Attribution license (http://creativecommons.org/licenses/by/3.0/). 